\title{
Expression Profiles of TGF- $\beta$ and TLR Pathways in Porphyromonas gingivalis and Prevotella intermedia Challenged Osteoblasts
}

\author{
Kubra Aydin ${ }^{1}$; Fatma Yesim Ekinci ${ }^{1}$; May Korachi ${ }^{1, *}$ \\ ${ }^{1}$ Department of Genetics and Bioengineering, Yeditepe University, Istanbul, Turkey \\ ${ }^{*}$ Corresponding author: May Korachi, Department of Genetics and Bioengineering, Yeditepe University, Istanbul, Turkey. Tel: $+90-2165782653$, Fax: $+90-2165780829$, \\ E-mail: mkorachi@yeditepe.edu.tr
}

Received: January 29, 2014; Revised: July 14, 2014; Accepted: July 25, 2014

\begin{abstract}
Background: The presence of certain oral pathogens at implant sites can hinder the osseointegration process. However, it is unclear how and by what microorganisms it happens.

Objectives: This study investigated whether the presence of oral pathogens of Porphyromonas gingivalis and Prevotella intermedia individually, play a role in the failure of bone formation by determining the expression profiles of Transforming Growth Factor Beta (TGF$\beta /$ Bone Morphogenic Protein (BMP) and Toll-Like Receptor(TLR) pathways in challenged osteoblasts.

Materials and Methods: Cell viability of $P$. gingivalis and $P$. intermedia challenged osteoblasts were determined by WST assay. Changes in osteoblast morphology and inhibition of mineralization were observed by Scanning Electron Microscopy (SEM) and Von Kossa staining, respectively. Expression of TGF- $\beta$ and TLR pathway genes on challenged cells were identified by RT profiler array. Both $P$. gingivalis and $P$. intermedia challenges resulted in reduced viability and mineralization of osteoblasts.

Results:Viability was reduced to 56.8\%(P.gingivalis)and 52.75\%(P. intermedia) at 1000 multiplicity. Amongst 48 genes examined, expressions of BMPER, SMAD1, IL8 and NFRKB were found to be highly upregulated by both bacterial challenges (Fold Change > 4).

Conclusions:P. gingivalis and P. intermedia could play a role in implant failure by changing the expression profiles of genes related to bone formation and resorption.
\end{abstract}

Keywords: Receptors Transforming Growth Factor; Receptors, Toll Like; Bone Formation; Osseointegration

\section{Background}

Dental implants are a reliable oral and maxillofacial rehabilitation treatment modality. Despite high success rate, implant fixture failure may occur and approximately $2 \%$ of this failures have been associated with the failure in osseointegration (1). Osteoblasts play a crucial role for establishing or maintaining osseointegration since they directly differentiate from mesenchymal stem cells and produce the characteristic extracellular matrix that includes collagenous and non-collagenous proteins, Bone Morphogenetic Proteins (BMP), and growth factors (required for bone mineralization) (2). Osseointegration may be inhibited by bacterial or viral infections, which trigger the inflammatory response via cytokine regulation, thus decreasing the synthesis of the extracellular matrix (3). Implant failure cannot be related to a specific microorganism, but certain bacteria are present more frequently around failing implants, including Porphyromonas gingivalis and Prevotella intermedia (4). These are black pigmented, Gram negative, anaerobic pathogens that have multiple virulence factors such as lipopolysaccharide (LPS) and gingipains, which facilitate the adhesion and invasion of cells $(5,6)$.
Interactions between the pathogen and host cells lead to the degradation of the extracellular matrix and activation of gene expression; however, the genetic profiles of infected cells differ among various microorganisms (7). In this respect, pro-inflammatory and regulatory cytokines are key elements in determining disease progression. Of these cytokines, Transforming Growth Factor Beta (TGF- $\beta$ ) and Toll-Like Receptor (TLR) pathways related genes are critical elements in the control of tissue destruction and regeneration. Various genes of these pathways have previously shown links to creating an immune response to microbes, bone formation, and resorption (810). Porphyromonas. gingivalis is capable of interrupting the host immune system by inducing human peripheral macrophages and neutrophils to overproduce several proinflammatory cytokines such as interleukin-1 (IL-1), IL6, and Tumor Necrosis Factor Alpha (TNFa) (11). Also, P. intermedia induces interleukin-8 (IL-8) and mitogen activated protein kinases in monocytes, macrophages, endothelial cells, and gingival fibroblasts (12-14).

Other genes believed to be involved in bone formation are alkaline-phosphatase $(A L P)$ and Biglycan (BGN) (15). 
Aydin Ket al.

$A L P$ is one of the main constitutions of bone extracellular matrix and has been used as a marker to determine bone formation (16). Another gene known to play a role in regulating bone formation and matrix mineralization is BGN, a member of the Small Leucine-Rich Proteoglycan (SLRP) family found in bone extracellular matrix. $B G N$ modulates osteoblast differentiation, possibly by regulating BMP signaling and consequently matrix mineralization (15).

\section{Objectives}

This study focuses on determining the effects of oral pathogens; $P$. gingivalis and $P$. intermedia, on cell viability, matrix mineralization, and expression profiles of proinflammatory mediators and cytokine receptors in TGF- $\beta$ and TLR pathways as markers for implant failure.

\section{Materials and Methods}

\subsection{Bacterial Strains and Culture Conditions}

Prevotella. intermedia (ATCC 25611) and P. gingivalis (ATCC 33277) cultures were obtained from the American Type Culture Collection (ATCC, USA). Microorganisms were cultured on Brain Heart Infusion Agar (BHIA) supplemented with 5\% sheep blood (Salubris, Turkey) and incubated in an anaerobic workstation (Don Whitley, UK) at $37^{\circ} \mathrm{C}$, in an atmosphere of $80 \% \mathrm{~N}_{2}, 10 \% \mathrm{H}_{2}$, and $10 \% \mathrm{CO}_{2}$ (HABAS, Turkey) for 3 - $4 \mathrm{~d}$. Cultures were then maintained by sub-culturing every $2-3 \mathrm{~d}$.

\subsection{Cell Culture and Bacterial Challenge of the Human Fetal Osteoblast Cell Line}

The Human Fetal Osteoblast Cell Line (hFOB 1.19) was obtained from the American Type Cell Culture Collection (ATCC, USA). Cells were cultured in Dulbecco's Modified Eagle's Nutrient Mixture F-12 (DMEM F-12) (Invitrogen, Germany) supplemented with $10 \%$ heat inactivated Fetal Bovine Serum (FBS) (Invitrogen, Germany), 100 U/ $\mathrm{mL}$ penicillin, and $100 \mu \mathrm{g} / \mathrm{mL}$ streptomycin (Invitrogen, Germany) in a $5 \% \mathrm{CO}_{2}$ incubator (Nuaire NU5510/E/G, USA) at $37^{\circ} \mathrm{C}$. Human FOB cells were seeded at a density of $3 \times 10^{4} \mathrm{cell} / \mathrm{cm}^{2}$ and allowed to attach overnight. Bacteria in the exponential phase of growth were washed and resuspended in the antibiotic-free DMEM-F12 at concentrations equivalent to multiplicities of infections (MOI, bacteria: cell ratio) of 100, 250, 500, and 1000 . The MOIs of the inoculums were confirmed by plating serial 10 -fold dilutions of $P$. gingivalis and $P$. intermedia anaerobically on BHIA and calculating the Colony Forming Units (CFU's) following incubation. Cells were then cultured in the presence or absence of $P$. gingivalis and $P$. intermedia at different multiplicities of infections for 2 hours in a humidified atmosphere of $5 \% \mathrm{CO}_{2}$ at $37^{\circ} \mathrm{C}$. Experiments were carried out in triplicate cultures and 3 independent experiments were performed.

\subsection{WST Assay}

The effects of $P$. gingivalis and or P. intermedia challenge to viability of hFOBs were determined by measuring the mitochondrial dehydrogenase activity using the commercially available WST assay (Roche, Germany). Briefly, hFOB cells were challenged with $P$. gingivalis and $P$. intermedia at MOI of 100, 250, 500, and 1000 for 2 hours. Cells were then washed 3 times with Phosphate Buffer Saline (PBS) (Invitrogen, Germany) and incubated with DMEM F-12 supplemented with $200 \mu \mathrm{g} / \mathrm{mL}$ of metronidazole (Sigma-Aldrich, Germany), $300 \mu \mathrm{g} / \mathrm{mL}$ of gentamicin (Sigma-Aldrich, Germany) for 2 hours in $5 \% \mathrm{CO}_{2}$ at $37^{\circ} \mathrm{C}$ in order to kill any extracellular bacteria. A WST reagent was then applied to hFOBs according to the manufacturer's instructions. The absorbance was measured at $450 \mathrm{~nm}$ by a spectrophotometric plate reader (Bio-Tek ELx800, Germany). The values obtained represented the mean percentage $( \pm S D)$ from 3 independent experiments.

\subsection{Scanning Electron Microscopy}

Monolayers of hFOBs were grown on 13-mm-diameter sterile plastic cell-culture coverslips (Nalge Nunc, NY USA) and were individually challenged with either P. gingivalis or P. intermedia at $1000 \mathrm{MOI}$. Following incubation, monolayers were washed with $1 \mathrm{~mL}$ of PBS ( $\mathrm{pH} 7.2$ ) and fixed with $2 \%$ glutaraldehyde in $0.1 \mathrm{M}$ sodium cacodylate buffer (Sigma-Aldrich, Germany) pH 7.2, for 2 hours at $4^{\circ} \mathrm{C}$. The samples were then washed 3 times in sodium cacodylate buffer (Sigma-Aldrich, Germany) and further dehydrated in a graded series of ethanol (Sigma-Aldrich, Germany) at room temperature and dried at critical point. Dehydrated samples were gold sputtered (Bal-Tec, Liechtenstein) for 5 minutes and examined by a 247 Zeiss evo40 SEM (Zeiss, Carl Zeiss SMT, Germany).

\subsection{Assessment of Matrix Mineralization}

Matrix mineralization of osteoblasts was assessed by using the modified Von Kossa silver nitrate staining method (17). Briefly, hFOB cells were cultured in the presence or absence of either $P$. gingivalis or P. intermedia at 1000 MOI. Then, hFOB cells were fixed in $2 \%$ paraformaldehyde (Sigma-Aldrich, Germany) for 30 minutes at $4^{\circ} \mathrm{C}$. Following rinsing with $\mathrm{PBS}$, the fixed plates were incubated with freshly prepared 3\% silver nitrate solution (Merck, Germany) and exposed to UV light for 1 hour. Unreacted silver was then removed by incubation with $5 \%$ sodium thiosulphate (Merck, Germany) for 5 minutes and rinsed with distilled water. The cultures were then visualized by an inverted light microscope (Nikon Eclipse TS100, Japan) at $40 \times$ magnification.

\subsection{RNA Extraction and cDNA Synthesis}

Following bacterial challenge (MOI 1000), the culture supernatants were removed from the culture and the cell monolayers were washed twice in PBS before being lysed. 
Aydin Ket al.

Total RNA was extracted from the collected cell lysate using the RNeasy Mini Kit (Qiagen, Germany), according to the manufacturer's instructions. RNA concentrations were measured using a NanoDrop spectrophotometer (NanoImplen, Germany). One microgram of total RNA was then reverse transcribed into single-stranded cDNA by using RT ${ }^{2}$ First Strand Kit (SABiosciences, Qiagen, Germany) according to the manufacturer's instructions.

\subsection{Real-Time Polymerase Chain Reaction Profiler Array}

Gene expressions of TGF- $\beta$ and TLR pathway were determined with RT profiler human Toll-Like receptor signaling pathway and TGF- $\beta$ or BMP signaling pathway PCR array (SABiosciences, PAHS-035, and PAHS-018, respectively). A mixture of $1 \mu \mathrm{g}$ of $\mathrm{cDNA}, 1350 \mu \mathrm{L}$ RT-PCR SYBR green (Qiagen, Germany), and $1248 \mu \mathrm{L}$ RNase free water was prepared and $25 \mu \mathrm{L}$ of it was aliquoted into each well. Amplification was performed in a fluorescence thermocycler (Bio-Rad Laboratories, Germany) under the following conditions: initial denaturation at $95^{\circ} \mathrm{C}$ for 15 minutes, followed by 40 cycles of denaturation at $95^{\circ} \mathrm{C}$ for $15 \mathrm{sec}$ onds, finally annealing at $60^{\circ} \mathrm{C}$ for 1 minute. The specificity of PCR product was verified by melting curve analysis. The results obtained from PCR arrays were analyzed using a computer program RT Profiler PCR Array Data Analysis version 3.5 available at the company website (http:// www.sabiosciences.com).

\subsection{Quantitative Real Time Polymerase Chain Reaction}

$B G N$ and $A L P$ genes, related to matrix mineralization and osseointegration were manually studied. Glyceraldehyde-3-phosphate dehydrogenase (GAPDH) was used as an endogenous RNA control in the samples (Housekeeping gene, $\mathrm{HKG}$ ). qPCR was performed using $2.0 \mu \mathrm{L}$ of cDNA in a $25 \mu \mathrm{L}$ SYBR green reaction mix (Qiagen, Germany) for 15 minutes at $95^{\circ} \mathrm{C}$ and 40 cycles of 10 seconds at $95^{\circ} \mathrm{C}$, annealing at $58^{\circ} \mathrm{C}$ for 1 minute. The specificity of PCR product was verified by melting curve analysis. The relative expressions compared to the HKG were calculated by the comparative $\mathrm{Ct}$ method ( $2 \Delta \mathrm{Ct}$ formula) following normalization to GAPDH. The primers were used as follows: GAPDH 5'-TCCATGACAACTTTGGTATCG-3', 5' TGTAGC-
CAAATTCGTTGTCA-3', (18), Alkaline phosphatase (ALP) 5'-CTTGACTGTGGTTACTGCTG-3'; ALP, 5'-GAGCGTAATCTACCATGGAG-3'., (19), Biglycan (BGN), 5'-CTCAACTACCTGCGCATCTCAG-3', 5'-GATGGCCTGGATTTTGTTGTG-3' (ALPha DNA, Canada)(20).

\section{Results}

Cell viability of challenged hFOB cells showed a marked decrease (in a dose-dependent manner) in cell viability following both P. gingivalis and P. intermedia challenges. At the highest MOI of 1000, the viability was observed to reduce to $56.8 \%$ (P. gingivalis) and $52.75 \%$ (P. intermedia). No significant difference was observed between the two species at all MOI $(\mathrm{P}>0.05)$. The effects of bacterial challenge on osteoblast morphology were observed by SEM. Osteoblasts with a normal flattened fibroblast-like morphology were seen to detach and change to a more spherical one in P. gingivalis challenged cells (Figure 1), suggesting cell death. Similar results were observed for $P$. intermedia challenged osteoblasts. The negative effects of both $P$. gingivalis and $P$. intermedia were verified by a large reduction in mineralization of the osteoblasts.

The panel of cytokine genes and receptor pathways were selected (Tables 1 and 2), either according to their association with bone morphogenesis or because they are genes coding for important inflammation-associated molecules that may be involved in the bacterial challenge process. Array results confirmed the detrimental effect of the presence of these oral pathogens on bone formation. Overall, the BMP receptors (BMPRs) and activin receptors (ACVRs) were seen to be highly upregulated, with bone morphogenetic protein receptor, type IB (BMPR1B) showing the highest fold increase following $P$. gingivalis challenge and BMP binding Endothelial Regulator (BMPER) for $P$. intermedia challenged cells. The direction of expression was differentially regulated in Collagen, type I, ALPha 1 (COL1A1), Collagen, type I, ALPha 2 (COL1A2), osteocalcin $(O C)$, and Bone Morphogenetic Protein Receptor, type IA (BMPR1A) for P. gingivalis and P. intermedia. A downregulation was observed for $P$. gingivalis infected cells in comparison to an upregulation observed following P. intermedia challenge. A reduction in matrix mineralization was observed in P. gingivalis challenged cells following Von Kossa staining. Conversely, an upregulation was observed in P. intermedia challenged cells for COL1, OC, and BMPR1A.

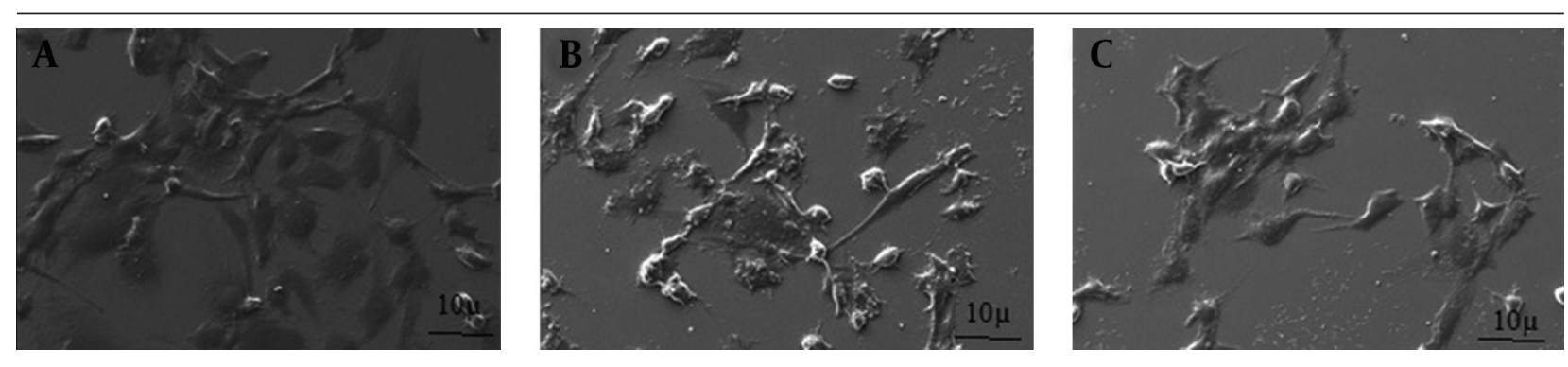

Figure 1. Scanning Electron Microscopy Images of Challenged Osteoblasts by Porphyromonas gingivalis and Prevotella intermedia at a MOI of 1000 for 2 Hours 
Aydin Ket al.

\begin{tabular}{|c|c|c|c|c|}
\hline \multirow{2}{*}{ Gene Description } & \multirow{2}{*}{ Gene Symbol } & \multirow{2}{*}{ Accession No ${ }^{a}$} & \multicolumn{2}{|c|}{ Fold Change } \\
\hline & & & Porphyromonas gingivalis ${ }^{\mathrm{b}}$ & Prevotella intermedia ${ }^{\mathrm{c}}$ \\
\hline Activin A receptor, type I & $A C V R 2 A$ & NM-001616 & 3.34 & 6.681 \\
\hline Osteocalcin & $O C$ & NM-199173 & 0.895 & 3.58 \\
\hline BMP binding endothelial regulator & BMPER & NM-133468 & 5.816 & 23.264 \\
\hline $\begin{array}{l}\text { Bone morphogenetic protein recep- } \\
\text { tor, type IA }\end{array}$ & BMPR1A & NM-004329 & 0.551 & 7.674 \\
\hline $\begin{array}{l}\text { Bone morphogenetic protein recep- } \\
\text { tor, type IB }\end{array}$ & $B M P R 1 B$ & NM-001203 & 40.504 & 3.58 \\
\hline $\begin{array}{l}\text { Bone morphogenetic protein recep- } \\
\text { tor, type II }\end{array}$ & BMPR2 & NM-001204 & 14.32 & 5.816 \\
\hline Collagen, type I, alpha 1 & COL1A1 & NM-000088 & 0.24 & 13.361 \\
\hline Collagen, type I, alpha 2 & COL1A2 & NM-000089 & 0.008 & 6.233 \\
\hline Collagen, type III, alpha 1 & COL3A1 & NM-000090 & 1.919 & 3.58 \\
\hline SMAD family member 1 & Smad1 & NM-005900 & 4.113 & 15.348 \\
\hline SMAD family member 2 & Smad2 & NM-005901 & 0.895 & 3.117 \\
\hline SMAD family member 3 & Smad3 & NM-005902 & 0.004 & 0.678 \\
\hline SMAD family member 4 & Smad4 & NM-005359 & 0.003 & 4.724 \\
\hline SMAD family member 5 & Smad5 & NM-005903 & 0.016 & 0.148 \\
\hline $\begin{array}{l}\text { SMAD specific E3 ubiquitin protein } \\
\text { ligase } 1\end{array}$ & SMURF1 & NM-020429 & 0.678 & 10.126 \\
\hline $\begin{array}{l}\text { Signal transducer and activator of } \\
\text { transcription 1, 91kDa }\end{array}$ & STAT1 & NM-007315 & 0.002 & 6.681 \\
\hline Runt-relatedtranscription factor 1 & RUNX1 & NM-001754 & 1.454 & 11.632 \\
\hline $\begin{array}{l}\text { Serpin peptidase inhibitor, clade E, } \\
\text { member } 1\end{array}$ & SERPINE1 & NM-000602 & 0.021 & 10.126 \\
\hline $\begin{array}{l}\text { Transforming growth factor, beta- } \\
\text { induced, } 68 \mathrm{kDa}\end{array}$ & TGFB1 & NM-000660 & 0.042 & 6.233 \\
\hline $\begin{array}{l}\text { Transforming growth factor, beta } \\
\text { receptor } 1\end{array}$ & TGFBR1 & NM-004612 & 3.58 & 1.454 \\
\hline $\begin{array}{l}\text { Transforming growth factor, beta } \\
\text { receptor } 2\end{array}$ & TGFBR2 & NM-003242 & 0.097 & 0.182 \\
\hline $\begin{array}{l}\text { Transforming growth factor, beta } \\
\text { receptor } 3\end{array}$ & TGFBR3 & NM-003243 & 3.117 & 0.514 \\
\hline TGFB-induced factor homeobox 1 & TGIF1 & NM-003244 & 0.097 & 0.633 \\
\hline $\begin{array}{l}\text { Latent transforming growth factor } \\
\text { beta binding protein } 1\end{array}$ & LTBP1 & NM-000627 & 0.678 & 2.713 \\
\hline $\begin{array}{l}\text { Latent transforming growth factor } \\
\text { beta binding protein } 2\end{array}$ & LTBP2 & NM-000428 & 3.117 & 2.908 \\
\hline $\begin{array}{l}\text { Latent transforming growth factor } \\
\text { beta binding protein } 4\end{array}$ & LTBP4 & NM-003573 & 1.028 & 0.418 \\
\hline
\end{tabular}

\footnotetext{
a Fold change value of a gene following $P$. gingivalis challenge.

$\mathrm{b}$ Fold change value of a gene following P. intermedia challenge. Fold change of mRNA level was calculated relative to the expression value in non-

challenged cells. Fold-change values less than one indicate a negative or down-regulation

$\mathrm{C}$ Accession numbers indicate the sequence used as Super Array analysis.
} 
Aydin Ket al.

Table 2. Fold Change of TLR Pathway Genes in hFOB Cells Following Challenge by Porphyromonas gingivalis or Prevotella intermedia

\begin{tabular}{|c|c|c|c|c|}
\hline \multirow{2}{*}{ Gene Description } & \multirow{2}{*}{ Gene Symbol } & \multirow{2}{*}{ Accession $\mathrm{No}^{\mathrm{a}}$} & \multicolumn{2}{|c|}{ Fold Change } \\
\hline & & & Porphyromonas gingivalis ${ }^{\mathrm{b}}$ & Prevotella intermedia $^{\mathrm{c}}$ \\
\hline Toll-like receptor 3 & TLR3 & NM-003265 & 0.025 & 0.021 \\
\hline Toll-like receptor 4 & TLR4 & NM-138554 & 1.231 & 2.144 \\
\hline Toll-like receptor 5 & TLR5 & NM-003268 & 0.002 & 0.00 \\
\hline Toll-like receptor 6 & TLR6 & NM-006068 & 0.002 & 0.005 \\
\hline $\begin{array}{l}\text { Myeloid differentiation pri- } \\
\text { mary response gene }(88)\end{array}$ & MYD88 & NM-002468 & 1.741 & 3.482 \\
\hline Toll interacting protein & TOLLIP & NM-019009 & 3.732 & 1.516 \\
\hline $\begin{array}{l}\text { Toll-like receptor adaptor } \\
\text { molecule } 1\end{array}$ & TICAM1 & NM-182919 & 1.414 & 1.072 \\
\hline $\begin{array}{l}\text { Toll-like receptor adaptor } \\
\text { molecule } 2\end{array}$ & TICAM2 & NM-021649 & 0.095 & 0.354 \\
\hline Interleukin 12A & IL12A & NM-000882 & 0.009 & 0.006 \\
\hline Interleukin $1 \mathrm{~A}$ & IL1A & NM-000575 & 0.467 & 0.379 \\
\hline Interleukin 1B & IL1B & NM-000576 & 0.536 & 0.536 \\
\hline Interleukin 6 & IL6 & NM-000600 & 0.354 & 0.083 \\
\hline Interleukin 8 & IL8 & NM-000584 & 17.148 & 12.126 \\
\hline $\begin{array}{l}\text { Interleukin-1 receptor-associ- } \\
\text { ated kinase } 1\end{array}$ & IRAK1 & NM-001569 & 0.095 & 0.144 \\
\hline $\begin{array}{l}\text { Interleukin-1 receptor-associ- } \\
\text { ated kinase } 2\end{array}$ & IRAK2 & NM-001570 & 3.031 & 5.657 \\
\hline $\begin{array}{l}\text { Nuclear factor of kappa light } \\
\text { polypeptide gene enhancer } \\
\text { in B-cells } 1\end{array}$ & NFKB1 & NM-003998 & 2 & 1.866 \\
\hline NFKB inhibitor, alpha & NFKBIA & NM-003998 & 0.707 & 0,33 \\
\hline $\begin{array}{l}\text { Nuclear factor related to kap- } \\
\text { paB binding protein }\end{array}$ & $N F R K B$ & NM-006165 & 6.498 & 21.112 \\
\hline $\begin{array}{l}\text { Mitogen-activated protein } \\
\text { kinase kinase } 3\end{array}$ & MAP2K3 & NM-002756 & 0.203 & 0.095 \\
\hline $\begin{array}{l}\text { Mitogen-activated protein } \\
\text { kinase kinase } 4\end{array}$ & MAP2K4 & NM-003010 & 0.117 & 0.154 \\
\hline $\begin{array}{l}\text { Mitogen-activated protein } \\
\text { kinase kinase kinase } 1\end{array}$ & МАРЗК1 & NM-005921 & 0.014 & 0.016 \\
\hline $\begin{array}{l}\text { Mitogen-activated protein } \\
\text { kinase kinase kinase kinase } 4\end{array}$ & MAP4K4 & NM-004834 & 1.32 & 1 \\
\hline
\end{tabular}

\footnotetext{
a Accession numbers indicate the sequence used as Super Array analysis.

$\mathrm{b}$ Fold change value of a gene following $P$. gingivalis challenge.

c Fold change value of a gene following P. intermedia challenge. Fold change of mRNA level was calculated relative to the expression value in nonchallenged cells. Fold-change values less than one indicate a negative or downregulation.
}

Smad genes were also examined. $P$. gingivalis displayed an overall marked downregulation of these genes except in Smad family member 1 (Smad1). On the other hand, P. intermedia showed high upregulation of all the Smad family genes with the exception of Smad family member 3 (Smad3) and Smad family member 5 (Smad5). In this study, TGF- $\beta$ receptors were studied for their relation to bone formation. In general $P$. gingivalis challenged cells were downregulated. Transforming Growth Factor Beta (TGFB1) and Transforming Growth Factor Beta Receptor (TGFBR3), were seen to be highly expressed in P. intermedia and $P$. gingivalis, respectively. Furthermore, an increase in gene expression of Toll-like Receptor 4 (TLR4), MYD88, Interleukin-1 Receptor-Associated Kinase 2 (IRAK2) and $N F-\kappa B$ were observed. On the otherhand, the expressions of TLRs 3, 5, and 6 and all interleukins with the exception of IL8, were downregulated by both bacterial challenges. The levels of Mitogen-Activated Protein Kinase Kinase 3 (MAP2K3), Mitogen-Activated Protein Kinase Kinase 4 (MAP2K4) and Mitogen-Activated Protein Kinase Kinase Kinase 1 (MAP3K1) expression were decreased by $P$. gingivalis and $P$. intermedia challenge. Conversely, expression 
Aydin Ket al.

of Mitogen-Activated Protein Kinase Kinase Kinase Kinase 4 (MAP4K4) showed an upregulation by $P$. gingivalis challenge. In addition, $A L P$ and $B G N$ were also studied by manual qPCR. Fold regulations of these genes are shown in Figure 2. Expression of $A L P$ was seen to increase in P. gingivalis challenge, and decrease in P. intermedia challenge. The opposite was observed for BGN expression levels.

Figure 2. Relative Gene Expression (Fold Change) was Determined by Real-Time PCR Using Specific Primers to ALP and BGN Genes Following Bacterial Challenges

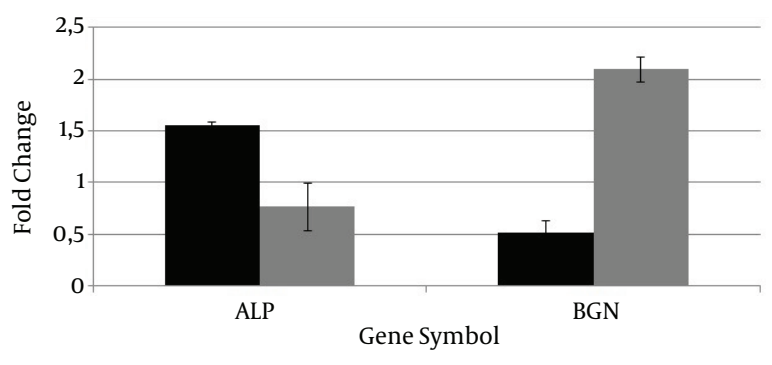

The gene expression of Porphyromonas gingivalis challenged osteoblasts is shown as black bars. The gene expression of Prevotella intermedia challenged osteoblasts is shown as grey bars.

\section{Discussion}

In this study no significant difference was observed between the $P$. gingivalis and $P$. intermedia MOI $(\mathrm{P}>0.05)$. These findings were similar to those of Kadono et al. (13), who found that $P$. gingivalis cell invasion adversely affected osteoblasts differentiation and activity. Although a previous study by Zhang et al. showed that an increase in bacterial concentration gave way to more bacterial invasion of the cell, this did not affect cell viability or proliferation (21). The difference between these results could be due to different methods used for measuring cell viability. SEM results showed a large reduction in mineralization of the osteoblasts. These findings have previously been observed in mouse calvarial osteoblasts following $P$. gingivalis invasion (21). Similar observations have been documented for $P$. intermedia challenged cells where a reduction in alkaline phosphatase activity and calcium incorporation were seen (22).

It has been previously shown that upregulation of $B M$ PER inhibits bone morphogenetic protein 2 (BMP2) and bone morphogenetic protein 4 (BMP4), dependent osteoblast differentiation and BMP-dependent differentiation of the chondrogenic cells (23). The BMPR-1B gene has been suggested as a therapeutic target for enhancing bone regeneration in vivo (24). The converse upregulation following bacterial challenge could suggest a repairing mechanism of this gene in order to inhibit negative effects of bacterial presence. These genes are known to play role in matrix mineralization $(25,26)$.

Collagen, the most abundant organic component of bone has a structural function. Type I and III collagens have been implicated as regulatory molecules for the differentiation and proliferation of human osteoblastic cells, and as a possible new target for the treatment of osteoporosis, although collagen III is found at very low level in the bone matrix (27). The reduction in matrix mineralization observed in P. gingivalis challenged cells following Von Kossa staining is in accordance with the downregulation of COL1A1 and COL1A2. However, an upregulation was observed in P. intermedia challenged cells for COL1, OC, and BMPR1A. It has previously been suggested that deletion of $O C$ increases bone mass (28). These differences in gene expressions suggest that $P$. gingivalis and $P$. intermedia might have different mechanisms in inhibiting matrix mineralization of osteoblasts.

Genes from the mothers against decapentaplegic homolog (Smad family) were also examined. A marked difference in the expression of $P$. gingivalis and $P$. intermedia infected cells was observed. P. gingivalis displayed an overall marked downregulation of these genes except in Smad family member 1 (Smad1). On the other hand, $P$. intermedia showed high upregulation of all the Smad family genes with the exception of Smad family member 3 (Smad3) and Smad family member 5 (Smad5). The Smad gene family provides instructions for producing proteins that help regulate the activity of particular genes as well as cell growth and proliferation (29). The downregulation of Smad3 and Smad5 by both $P$. gingivalis and $P$. intermedia is in accordance with findings that showed a deletion of these genes lower the rate of bone formation and mineralization (30). The dowregulation could be due to positively regulated BMPER since it is known that BMPER antagonizes BMP4-dependent Smad5 activation (23).

In this study, TGF- $\beta$ receptors were also studied for their relation to bone formation. In general $P$. gingivalis challenges cells showed downregulation. A study by Filvarof et al. showed that inhibition of TGF- $\beta$ receptor signaling in osteoblasts lead to decreased bone remodeling (31). This study confirmed these findings for both $P$. gingivalis and $P$. intermedia but was differential in the expressions of Transforming Growth Factor Beta-induced (TGFB1) and Transforming Growth Factor Beta Receptor (TGFBR3), which were seen to be highly expressed in P. intermedia and $P$. gingivalis, respectively.

In the TLR pathway, genes related to toll-like receptor, Interleukin 1 (IL), Mitogen-Activated Protein Kinase $(M A P)$, and Nuclear Factor-kappa-B (NF- $\kappa B)$ family were examined. All these pathways are known to play a role in bone regeneration and cell cycle (32-34). The expression profiles for TLRs were consistant with their known function of being pattern recognition receptors that recognize foreign substances in the body and activate immune system (35). Such an increase in gene expression of Toll-like Receptor 4 (TLR4) in human periodontal ligament cells challenged by P. intermedia has previously been observed (36). Sartori et al. (37) indicated that TLR4 signaling activates Myeloid Differentiation Primary Response gene 88 (MYD88) dependent pathways to subse- 
quent activation of Interleukin-1 Receptor-Associated Kinase (IRAK), TNF Receptor-Associated Factor 6 (TRAF6), and, ultimately $N F-\kappa B$, which is required for cytokine induction (37). Upregulation of MYD88, Interleukin-1 Receptor-Associated Kinase 2 (IRAK2) and NF- $\kappa B$ observed in this study is consistent with these findings. Similar findings have been reported in a study were an increase in the expression of MYD88 was found following Salmonella infection (38).

Our findings suggest that $P$. gingivalis and $P$. intermedia are likely to act via TLR4. The suppressed expressions of TLRs 3, 5, and 6 could be due to upregulation of Toll Interacting Protein (TOLLIP), an inhibitory adaptor protein which was also upregulated in this study (39). The IL family plays a central role in the regulation of immune and inflammatory responses. Interestingly the expressions of all interleukins apart from IL8 were downregulated by both bacterial challenges. Similar finding have shown IL8 to be upregulated by oxidative stress (40). Such an upregulation might be indicative of osteoblast infection by $P$. gingivalis and P. intermedia. The MAP family plays an important function in regulating the proinflammatory cytokines (41). Riewe et al. showed that $P$. gingivalis infection induced phosphorylation and activation of MAPK2K3 in human extravillous trophoblasts (42). Although there are not many studies on MAP3K1, an overexpression of MAP3K1 has previously been found in extramammary Paget's disease (43). Different results could be due to the different cell line and strains used. Interestingly, expression of MAP4K4 did not change in $P$. intermedia challenged cells.

The reduced expression of ALP could be related to the reduction in mineralization in $P$. intermedia challenged cells. Furthermore, the reduction in mineralization of osteoblasts by $P$. gingivalis challenge could be due to decreased expression of $B G N$. It was shown that $P$. gingivalis LPS's significantly delay normally high expression levels of BGN in rat alveolar bone osteoblasts (44).

In conclusion, the results of this study showed that both $P$. gingivalis and $P$. intermedia were capable of inhibiting osteoblast proliferation and therefore osseointegration. Both of these anaerobes were also seen to reduce matrix mineralization in osteoblast cells. Moreover, gene expression studies showed that $P$. gingivalis and $P$. intermedia induced TLR and TGF beta related genes, by upregulation or downregulation of their cytokines and receptors. Furthermore, differences were observed in the expression of several genes following $P$. gingivalis and $P$. intermedia challenge. These differences suggest that $P$. gingivalis and $P$. intermedia could have different mechanisms of inhibiting or reducing bone formation. The changes observed in the expression of key genes involved in bone resorption and formation indicates an important role for these bacteria in reducing osseointegration. The findings of this study confirm that both $P$. gingivalis and $P$. intermedia are risk factors for failure in bone formation and bone resorption.

\section{Acknowledgements}

We gratefully acknowledge Dr Philip S. Bird for providing Porphyromonas gingivalis (ATCC 33277) and Prevotella intermedia (ATCC 25611) strains.

\section{Authors' Contributions}

May Korachi: Study concept and design, drafting of the manuscript; Fatma Yesim Ekinci: Analysis and interpretation of data; Kubra Aydin: Performed all experiments.

\section{Funding/Support}

The study was supported by grants from The Scientific and Technological Research Council of Turkey (TUBITAK, SBAG-110S262).

\section{References}

1. Pye AD, Lockhart DE, Dawson MP, Murray CA, Smith AJ. A review of dental implants and infection. J Hosp Infect. 2009;72(2):104-10.

2. Chug A, Shukla S, Mahesh L, Jadwani S. OsseointegrationMolecular events at the bone-implant interface. JOMSMP. 2013;25:1-4.

3. Baker PJ. The role of immune responses in bone loss during periodontal disease. Microbes Infect. 2000;2(10):1181-92.

4. Heydenrijk K, Meijer HJ, van der Reijden WA, Raghoebar GM, Vissink A, Stegenga B. Microbiota around root-form endosseous implants: a review of the literature. Int J Oral Maxillofac Implants. 2002;17(6):829-38.

5. Amano A, Nakagawa I, Okahashi N, Hamada N. Variations of Porphyromonas gingivalis fimbriae in relation to microbial pathogenesis. J Periodontal Res. 2004;39(2):136-42.

6. Guan SM, Zhang M, He JJ, Wu JZ. Mitogen-activated protein kinases and phosphatidylinositol 3-kinase are involved in Prevotella intermedia-induced proinflammatory cytokines expression in human periodontal ligament cells. Biochem Biophys Res Commun. 2009;386(3):471-6.

7. Feng Z, Weinberg A. Role of bacteria in health and disease of periodontal tissues. Periodontol 2000. 2006;40:50-76.

8. Chen G, Deng C, Li YP. TGF-beta and BMP signaling in osteoblast differentiation and bone formation. Int J Biol Sci. 2012;8(2):272-88.

9. Casanova JL, Abel L, Quintana-Murci L. Human TLRs and IL-1Rs in host defense: natural insights from evolutionary, epidemiological, and clinical genetics. Annu Rev Immunol. 2011;29:447-91.

10. Tang Y, Wu X, Lei W, Pang L, Wan C, Shi Z, et al. TGF-beta1-induced migration of bone mesenchymal stem cells couples bone resorption with formation. Nat Med. 2009;15(7):757-65.

11. Lin $\mathrm{X}, \mathrm{Wu}$ J, Xie H. Porphyromonas gingivalis minor fimbriae are required for cell-cell interactions. Infect Immun. 2006;74(10):6011-5.

12. Tamura M, Tokuda M, Nagaoka S, Takada H. Lipopolysaccharides of Bacteroides intermedius (Prevotella intermedia) and Bacteroides (Porphyromonas) gingivalis induce interleukin-8 gene expression in human gingival fibroblast cultures. Infect Immun. 1992;60(11):4932-7.

13. Kadono H, Kido J, Kataoka M, Yamauchi N, Nagata T. Inhibition of osteoblastic cell differentiation by lipopolysaccharide extract from Porphyromonas gingivalis. Infect Immun. 1999;67(6):2841-6.

14. Iki K, Kawahara K, Sawamura S, Arakaki R, Sakuta T, Sugiyama A, et al. A novel component different from endotoxin extracted from Prevotella intermedia ATCC 25611 activates lymphoid cells from $\mathrm{C} 3 \mathrm{H} / \mathrm{HeJ}$ mice and gingival fibroblasts from humans. Infect Immun. 1997;65(11):4531-8.

15. Parisuthiman D, Mochida Y, Duarte WR, Yamauchi M. Biglycan modulates osteoblast differentiation and matrix mineralization. J Bone Miner Res. 2005;20(10):1878-86.

16. Clarke B. Normal bone anatomy and physiology. Clin J Am Soc Nephrol. 2008;3 Suppl 3:S131-9. 
17. Gerstenfeld LC, Chipman SD, Glowacki J, Lian JB. Expression of differentiated function by mineralizing cultures of chicken osteoblasts. Dev Biol.1987;122(1):49-60.

18. Shin NR, Jeong EH, Choi CI, Moon HJ, Kwon CH, Chu IS, et al. Overexpression of Snail is associated with lymph node metastasis and poor prognosis in patients with gastric cancer. BMC Cancer. 2012;12:521.

19. Kim YJ, Lee MH, Wozney JM, Cho JY, Ryoo HM. Bone morphogenetic protein-2-induced alkaline phosphatase expression is stimulated by Dlx5 and repressed by Msx2. J Biol Chem. 2004;279(49):50773-80.

20. Corps AN, Robinson AH, Movin T, Costa ML, Hazleman BL, Riley GP. Increased expression of aggrecan and biglycan mRNA in Achilles tendinopathy. Rheumatology (Oxford). 2006;45(3):291-4.

21. Zhang W, Swearingen EB, Ju J, Rigney T, Tribble GD. Porphyromonas gingivalis invades osteoblasts and inhibits bone formation. Microbes Infect. 2010;12(11):838-45.

22. Pelt P, Zimmermann B, Ulbrich N, Bernimoulin JP. Effects of lipopolysaccharide extracted from Prevotella intermedia on bone formation and on the release of osteolytic mediators by fetal mouse osteoblasts in vitro. Arch Oral Biol. 2002;47(12):859-66.

23. Moser M, Binder O, Wu Y, Aitsebaomo J, Ren R, Bode C, et al. BMPER, a novel endothelial cell precursor-derived protein, antagonizes bone morphogenetic protein signaling and endothelial cell differentiation. Mol Cell Biol. 2003;23(16):5664-79.

24. Singhatanadgit W, Salih V, Olsen I. RNA interference of the BMPRIB gene blocks BMP-2-induced osteogenic gene expression in human bone cells. Cell Biol Int. 2008;32(11):1362-70.

25. Garcia-Martin A, Reyes-Garcia R, Avila-Rubio V, Munoz-Torres M Osteocalcin: a link between bone homeostasis and energy metabolism. Endocrinol Nutr. 2013;60(5):260-3.

26. Rodrigues AM, Caetano-Lopes J, Vale AC, Vidal B, Lopes A, Aleixo I, et al. Low osteocalcin/collagen type I bone gene expression ratio is associated with hip fragility fractures. Bone. 2012;51(6):981-9.

27. Maehata YM, Lee MCL, Hata RIH. Roles of Collagen Molecules in Growth and Differentiation of Human Osteoblasts. Oral Biosci J. 2009;51:72-80.

28. Ducy P, Desbois C, Boyce B, Pinero G, Story B, Dunstan C, et al. Increased bone formation in osteocalcin-deficient mice. Nature. 1996;382(6590):448-52.

29. Chen W, Fu X, Sheng Z. Review of current progress in the structure and function of Smad proteins. Chin Med J (Engl). 2002;115(3):446-50.

30. Hellingman CA, Davidson EN, Koevoet W, Vitters EL, van den Berg WB, van Osch GJ, et al. Smad signaling determines chondrogenic differentiation of bone-marrow-derived mesenchymal stem cells: inhibition of Smad1/5/8P prevents terminal differentiation and calcification. Tissue Eng Part A. 2011;17(78):1157-67.
31. Filvaroff E, Erlebacher A, Ye J, Gitelman SE, Lotz J, Heillman M, et al. Inhibition of TGF-beta receptor signaling in osteoblasts leads to decreased bone remodeling and increased trabecular bone mass. Development.1999;126(19):4267-79.

32. Jovcic G, Ivanovic Z, Biljanovic-Paunovic L, Bugarski D, Stosic-Grujicic S, Milenkovic P. The effect of IL-1 receptor antagonist on the proliferation of hematopoietic progenitor cells in regenerating bone marrow. Leukemia.1996;10(3):564-9.

33. Wilkinson MG, Millar JB. Control of the eukaryotic cell cycle by MAP kinase signaling pathways. FASEB J. 2000;14(14):2147-57.

34. Mogi M, Ozeki N, Nakamura H, Togari A. Dual roles for NF-kappaB activation in osteoblastic cells by serum deprivation: osteoblastic apoptosis and cell-cycle arrest. Bone. 2004;35(2):507-16.

35. Beutler B. Inferences, questions and possibilities in Toll-like receptor signalling. Nature. 2004;430(6996):257-63.

36. Sun Y, Shu R, Li CL, Zhang MZ. Gram-negative periodontal bacteria induce the activation of Toll-like receptors 2 and 4 , and cytokine production in human periodontal ligament cells. J Periodontol. 2010;81(10):1488-96.

37. Sartori R, Li F, Kirkwood KL. MAP kinase phosphatase-1 protects against inflammatory bone loss. J Dent Res. 2009;88(12):1125-30.

38. Talbot S, Totemeyer S, Yamamoto M, Akira S, Hughes K, Gray D et al. Toll-like receptor 4 signalling through MyD88 is essential to control Salmonella enterica serovar typhimurium infection, but not for the initiation of bacterial clearance. Immunology. 2009;128(4):472-83.

39. Zhang G, Ghosh S. Negative regulation of toll-like receptor-mediated signaling by Tollip. J Biol Chem. 2002;277(9):7059-65.

40. Fernandes AF, Zhou J, Zhang X, Bian Q, Sparrow J, Taylor A, et al. Oxidative inactivation of the proteasome in retinal pigment epithelial cells. A potential link between oxidative stress and upregulation of interleukin-8. J Biol Chem. 2008;283(30):20745-53.

41. Pearson G, Robinson F, Beers Gibson T, Xu BE, Karandikar $\mathrm{M}$, Berman $\mathrm{K}$, et al. Mitogen-activated protein (MAP) kinase pathways: regulation and physiological functions. Endocr Rev. 2001;22(2):153-83.

42. Riewe SD, Mans JJ, Hirano T, Katz J, Shiverick KT, Brown TA, et al. Human trophoblast responses to Porphyromonas gingivalis infection. Mol Oral Microbiol. 2010;25(4):252-9.

43. Qian Y, Takeuchi S, Dugu L, Tsuji G, Xie L, Nakahara T, et al. Hematopoietic progenitor kinase 1 , mitogen-activated protein/ extracellular signal-related protein kinase kinase kinase 1, and phosphomitogen-activated protein kinase kinase 4 are overexpressed in extramammary Paget disease. Am J Dermatopathol. 2011;33(7):681-6.

44. Roberts HC, Moseley R, Sloan AJ, Youde SJ, Waddington RJ. Lipopolysaccharide alters decorin and biglycan synthesis in rat alveolar bone osteoblasts: consequences for bone repair during periodontal disease. Eur J Oral Sci. 2008;116(3):207-16. 